\title{
The utilization of protein from a low-protein diet as determined by limiting essential amino acids
}

\author{
BY E. JABŁOŃSKI AND H. RAFALSKI* \\ Department of Human Nutrition Medical Academy, 90-251 Lodz, Jaracza Str 63, Poland
}

(Received 9 August 1982 - Accepted 13 September 1983)

\begin{abstract}
1. Protein utilization was determined by assay with low-protein diets limiting in one of nine essential amino acids. The diets contained $50 \mathrm{~g}$ protein $/ \mathrm{kg}$ and the amino acid score of the protein was 0.50 .

2. Protein utilization was found to be related to the particular limiting essential amino acids present.

3. The usefulness of Bender's (1965) standard amino acid requirement for the estimation of amino acid utilization from a low-protein diet is discussed.
\end{abstract}

We stated in an earlier publication (Rafalski et al. 1978) that the measured value for protein utilization (net protein utilization, NPU) may be higher than the expected level, expressed as an index of the amino acid score (AAS) for leucine, lysine and tryptophan with a low-protein diet. We questioned the accuracy of relating values derived from biologically determined indices (NPU, biological value (BV)) to those based on AAS since they are not numerically equal (see Block \& Mitchell 1946-7; Bender, 1965). Furthermore, our results did not agree with those of Bender (1965) who found that NPU of proteins whose biological quality is limited by essential amino acids other than the sulphur-amino acids and valine can be higher only when their AAS is lower than 0.40. Our results (Rafalski et al. 1978) showed that it was possible to obtain values for NPU and BV higher than the AAS when the AAS exceeded 0.40 .

Our experiment was done with rats of the same age as those used by Bender (1965) but the dietary protein level $(50 \mathrm{~g} / \mathrm{kg}$ ) was half that used by Bender (1965). Furthermore, we used diets based on protein sources containing the essential amino acids whereas Bender (1965) used mixtures of synthetic essential amino acids.

It is known that dietary protein level influences the level of protein utilization in the body, but the reason for the difference in values measured biologically (NPU) and those based on the AAS is not clear. We have suggested that the amount of protein as well as the particular limiting essential amino acids present influence protein utilization.

The aim of the present study was to estimate the influence of each of nine limiting essential amino acids on protein utilization from low-protein diets. We also assessed the usefulness of Bender's (1965) standard in determining amino acid utilization from a low-protein diet.

\section{EXPERIMENTAL}

Protein utilization was determined using the NPU method of Miller \& Bender (1955). BV was determined by the method of Mitchell (1924), with the following modification. BV was calculated as NPU/TD, where TD is the true digestibility which was determined experimentally.

Of the ten diets used in the study one was based simply on Miller \& Bender's (1955) protein-free diet. Each of the others was limiting in one out of nine essential amino acids. The diets contained $(\mathrm{g} / \mathrm{kg}): 44 \cdot 4-50 \cdot 0$ protein, 150 sucrose, 150 lard, 100 vitamin-mineral mixture, wheat starch to $1 \mathrm{~kg}$. Protein sources were gelatin, casein, egg albumin and free

\footnotetext{
* For reprints.
} 
Table 1. Composition $(\mathrm{g} / \mathrm{kg})$ of experimental diets given to rats

\begin{tabular}{|c|c|c|c|c|c|c|c|}
\hline Limiting amino acid & Gelatine & Casein & $\begin{array}{l}\text { Free amino } \\
\text { acids }\end{array}$ & Lard & Sucrose & $\begin{array}{c}\text { Vitamin- } \\
\text { mineral mixture } \dagger\end{array}$ & Starch \\
\hline $\begin{array}{l}\text { Sulphur-containing } \\
\text { amino acids }\end{array}$ & $15 \cdot 2$ & $37 \cdot 2$ & 3.9 & 150 & 150 & 100 & $551 \cdot 5$ \\
\hline Isoleucine & $28 \cdot 5$ & $11 \cdot 1$ & 4.8 & 150 & 150 & 100 & $555 \cdot 6$ \\
\hline Threonine & $29 \cdot 2$ & 8.9 & $6 \cdot 3$ & 150 & 150 & 100 & $568 \cdot 2$ \\
\hline Phenylalanine & $34 \cdot 3$ & $6 \cdot 1$ & $5 \cdot 7$ & 150 & 150 & 100 & 553.9 \\
\hline Leucine & $33 \cdot 2$ & $8 \cdot 3^{*}$ & $4 \cdot 0$ & 150 & 150 & 100 & $554 \cdot 5$ \\
\hline Methionine & $30 \cdot 0$ & 9.8 & 4.9 & 150 & 150 & 100 & $555 \cdot 3$ \\
\hline Tryptophan & $36 \cdot 1$ & - & $8 \cdot 4$ & 150 & 150 & 100 & 555.5 \\
\hline Valine & 10.0 & $15 \cdot 2$ & $19 \cdot 7$ & 150 & 150 & 100 & $555 \cdot 1$ \\
\hline Histidine & $32 \cdot 0$ & $5 \cdot 7$ & $6 \cdot 8$ & 150 & 150 & 100 & $555 \cdot 5$ \\
\hline Lysine & 一 & $17 \cdot 8$ & $26 \cdot 9$ & 150 & 150 & 100 & $555 \cdot 3$ \\
\hline Protein-free diet & - & - & - & 150 & 150 & 100 & $600 \cdot 0$ \\
\hline
\end{tabular}

* Egg albumin.

$\dagger$ Contained $(\mu \mathrm{g} / \mathrm{kg}$ diet); 2909 retinol, 42 ergocalciferol; $(\mathrm{mg} / \mathrm{kg}$ diet): 2.9 thiamin, 9.7 riboflavin, 1.9 pyridoxine, 0.05 cyanocobalamin, $16.4 \alpha$-tocopheryl acetate, 0.2 biotin, 1.0 menadione, 57.9 calcium pantothenate, 193 nicotinic acid, 1.9 folic acid, 193.0 myo-inositol, $579.2 p$-aminobenzoic acid, $579 \cdot 2$ choline, 20.8 monocalcium phosphate, 44 potasssium iodide, 37 sodium fluoride, 7 manganese sulphate, 3.7 copper iodide, 3.7 potassium aluminium sulphate, 3.7 zinc sulphate; $(\mathrm{g} / \mathrm{kg}$ diet $): 3.5$ sodium chloride, 20.0 potassium citrate, 0.8 ferrous citrate, 4.8 magnesium sulphate.

essential and non-essential amino acids. The compositions of the diets and proteins and amino acids contents are shown in Table 1 .

The amino acid composition of each of the proteins (Table 2) was calculated so that the quantity of limiting amino acids was half that in the target mixture devised by Bender (1965) for Wistar rats. Rats had ad lib. access to diets and water.

The AAS of each of the nine essential amino acids limiting the protein value of the diets was $0 \cdot 50$, in accordance with Bender's (1965) standard, and the AAS of the second limiting and other amino acids in the protein diets were in the range $0.8-0.9$ (Table 2).

As shown in Table 2, the protein mixtures varied only in the limiting amino acid and not in the relative amounts of essential amino acids or protein level, according to the requirements of the rats.

The experiment was carried out according to the method of Miller \& Bender (1955) using Wistar rats aged $30 \pm 1 \mathrm{~d}$. The animals were housed in groups of four and the results for each diet were obtained from four groups of four rats. Total nitrogen contents of the diets and the carcasses were determined by the Kjeldahl method.

\section{RESULTS AND DISCUSSION}

The mean dietary and essential amino acid intakes for four groups of four rats in a $10 \mathrm{~d}$ period are shown in Table 3.

The variation in intake for four groups of four rats given the same protein mixture was very small but the intakes of rats fed on different protein mixtures limited by one of nine essential amino acids were significantly different $(P<0.05)$. The dietary intake varied in the range $147 \cdot 3-218 \cdot 1 \mathrm{~g} /$ group per $10 \mathrm{~d}$, according to the kind of protein mixture.

Rats receiving protein in which lysine, valine, leucine, methionine, phenylalanine or the S-amino acids were limiting consumed the greatest amount of the diet $(184 \cdot 0-218 \cdot 1 \mathrm{~g})$. The rats given protein in which either isoleucine, threonine, histidine or tryptophan was limiting consumed the least amount of diet (147.3-168.2 g). Groups given protein diets consumed 


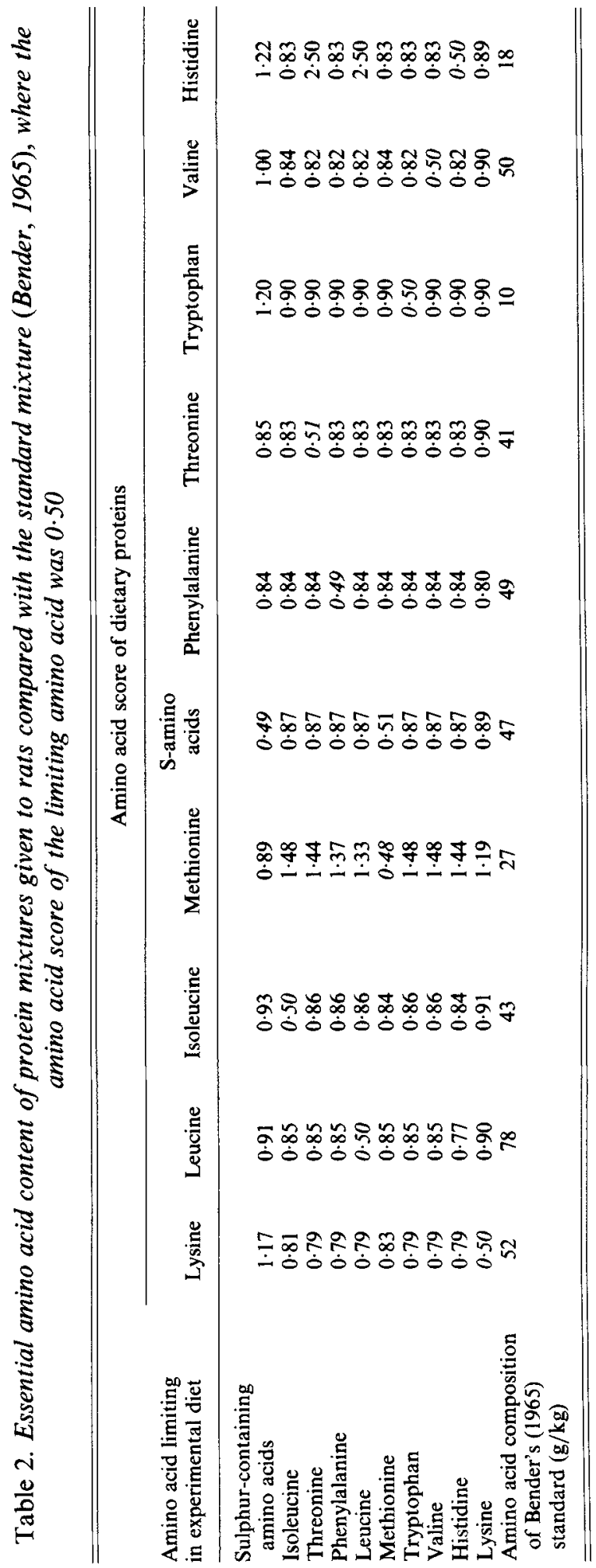


E. JABLOŃSKI AND H. RAFALSKI

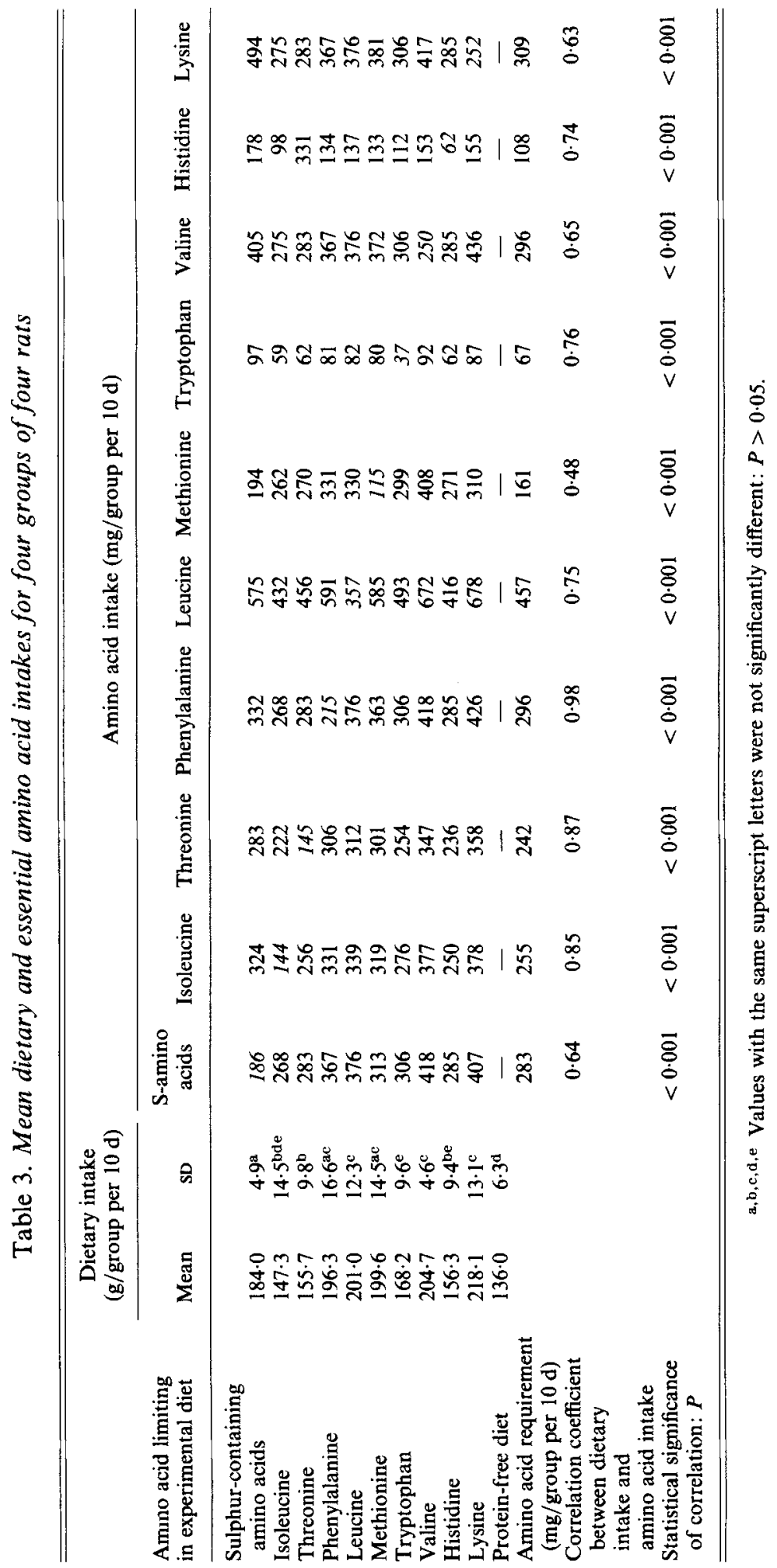


significantly more $(P<0.05)$ than those given protein-free diets $(136.0 \mathrm{~g} /$ group per $10 \mathrm{~d})$ except for the protein diets in which either isoleucine, tryptophan or histidine was limiting.

It was necessary to ensure that the energy intake on the low-protein diet was sufficient to meet the energy requirement of the rats and would not therefore affect protein utilization. The (US) National Academy of Sciences (1972) recommended that the energy requirement for a rat weighing $61 \mathrm{~g}$ is $0.052 \mathrm{MJ}(12.4 \mathrm{kcal}) / \mathrm{d}$ to maintain body-weight.

The mean initial weight of individual rats given the low-protein diets was $61 \mathrm{~g}$ (group mean 243 (SE 1) g). They were given isoenergetic diets containing $0.019 \mathrm{MJ}(4.55 \mathrm{kcal}) / \mathrm{kg}$. The lowest daily intake $(3.7 \mathrm{~g} \times 0.019 \mathrm{MJ}=0.069 \mathrm{MJ})$ and the highest intake $(5.4 \times$ $0.019 \mathrm{MJ}=0.113 \mathrm{MJ}$ ) were both higher than that recommended by the (US) National Academy of Sciences (1972). Therefore the diets received by the rats in our experiment met energy requirements and were adequate for the maintenance of body-weight. Meeting the energy requirements of the rat facilitated the assessment of the effect of limiting various essential amino acids on the normal utilization of protein.

Table 3 shows the intake of each of the essential amino acids in the protein mixture. Results indicated that the intake of each essential amino acid depended on its quantity and the total intake of diet. Following the recommendation of the (US) National Academy of Sciences (1972), the protein requirement of the rat at or below maintenance of body-weight can be met when the dietary protein level is $44.4 \mathrm{~g} / \mathrm{kg}$ and the composition of essential amino acids in the protein is in accordance with Bender's (1965) standard. Thus, the protein content of our diet $(44.4-50 \mathrm{~g}$ ) and the intake of essential amino acids was, except for the amino acid which was limiting, sufficient to meet the requirement of the rat for maintenance of body-weight. This was confirmed by the statistically significant correlation $(r 0.48-0.98$; $P<0.01-P<0.001$ ) between dietary intake and essential amino acid intake. Correlation coefficients are presented in Table 3. Only the lowest intake of the diet limiting in isoleucine did not meet the amino acid requirements of the rats according to Bender's (1965) standard.

The varying intakes of low-protein diets limiting in different essential amino acids influenced the final body-weight of the rats; at the start of the experiment all groups had the same body-weight (Table 4).

The correlation between dietary intake and final body-weight of the rats was very high $(r 0.89 ; P<0.01)$. All rats given the low-protein diets lost weight during the $10 \mathrm{~d}$ of the experiment. Body-weight losses, ranging from 1.4 to $0.4 \mathrm{~g} / \mathrm{d}$ per rat should not, as it is supposed, affect the values of NPU since the rats were close to maintenance state, which is the optimum state for assessing the protein utilization. The highest weight loss was observed in the rats given diets limiting in isoleucine, the S-amino acids and threonine. The weight loss of rats consuming protein limiting in isoleucine did not vary significantly $(P>0.05)$ from that of rats maintained on a non-protein diet, and this intake did not meet fully the requirement for essential amino acids. The weight loss of rats given protein limiting in other essential amino acids was significantly less $(P<0.05)$ than that of rats given diets limiting in isoleucine, threonine, the S-amino acids and the protein-free diet.

Based on body-weight loss on the different experimental diets the rats could be divided into three groups. The first included the diets limiting in isoleucine, threonine and the S-amino acids which gave a weight loss similar to that on the protein-free diet. The second group included the diets limiting in phenylalanine, leucine, tryptophan, valine and histidine, which produced a weight loss lower than that on the protein-free diet. The third group was that for which the least weight loss occurred and included only the diet limiting in lysine.

Table 4 gives values for protein utilization, measured by NPU and BV, with the AAS ( 0.50 for each essential amino acid).

It can be seen from Table 4 that only the values of NPU and BV for the protein limiting 
Table 4. Net protein utilization (NPU) and biological value (BV) compared with amino acid score ( $A A S ; 0.50$ for each protein mixture) and change in body-weight (g/group per $10 \mathrm{~d}$ ) of rats given experimental diets

\begin{tabular}{|c|c|c|c|c|c|c|}
\hline \multirow{2}{*}{$\begin{array}{l}\text { Amino acid limiting } \\
\text { in experimental diet }\end{array}$} & \multicolumn{2}{|c|}{ NPU } & \multicolumn{2}{|c|}{ BV } & \multicolumn{2}{|c|}{ Change in body-weight } \\
\hline & Mean & sD & Mean & SD & Mean & SD \\
\hline $\begin{array}{l}\text { Sulphur-containing } \\
\text { amino acids }\end{array}$ & $0 \cdot 49$ & $0.044^{a}$ & $0 \cdot 50$ & $0.044^{\mathrm{a}}$ & -50.9 & $4 \cdot 3^{\mathrm{a}}$ \\
\hline $\begin{array}{l}\text { Isoleucine } \\
\text { I }\end{array}$ & 0.51 & $0.051^{\mathrm{ab}}$ & 0.52 & $0.052^{\mathrm{ab}}$ & -55.0 & $6 \cdot 8^{\mathrm{aP}}$ \\
\hline Threonine & 0.51 & $0.036^{\mathrm{a}}$ & 0.51 & $0.026^{\mathrm{a}}$ & $-48 \cdot 8$ & $3 \cdot 6^{\mathrm{a}}$ \\
\hline Phenylalanine & 0.59 & $0.035^{\mathrm{bc}}$ & 0.60 & $0.035^{* \mathrm{bc}}$ & $-36 \cdot 1$ & $3 \cdot 1^{\mathrm{b}}$ \\
\hline Leucine & 0.65 & $0.034^{\mathrm{cd}}$ & 0.66 & $0.034^{* * \mathrm{~cd}}$ & $-28 \cdot 6$ & $2 \cdot 8^{\mathrm{ed}}$ \\
\hline Methionine & 0.66 & $0.031^{d}$ & 0.67 & $0.032^{* * d}$ & $-29 \cdot 2$ & $4 \cdot 2^{\mathrm{ee}}$ \\
\hline Tryptophan & 0.67 & $0.032^{\mathrm{d}}$ & 0.70 & $0.034^{* * \text { de }}$ & $-36 \cdot 9$ & $4 \cdot 5^{\mathrm{b}}$ \\
\hline Valine & 0.74 & $0.032^{\mathrm{e}}$ & 0.75 & $0.032^{* * * \mathrm{e}}$ & $-31 \cdot 7$ & $4 \cdot 1^{\text {bde }}$ \\
\hline Histidine & 0.85 & $0.021^{\mathrm{f}}$ & 0.85 & $0.021^{* * * 1}$ & $-33 \cdot 2$ & $4 \cdot 6^{\text {bde }}$ \\
\hline Lysine & 0.87 & $0.028^{\mathrm{f}}$ & 0.92 & $0.030^{* * * f}$ & -16.9 & $6 \cdot 1^{8}$ \\
\hline Protein-free diet & - & & - & & -61.5 & $2 \cdot 1^{\mathrm{p}}$ \\
\hline
\end{tabular}

a,b,c,d,e,f,g Values with the same superscript letters were not significantly different: $P>0 \cdot 05$. Values were significantly different from AAS of $0.50:{ }^{*} P<0.05,{ }^{* *} P<0.01,{ }^{* * *} P<0.001$.

in S-amino acids, isoleucine and threonine were the same as their AAS. The values of NPU and $\mathrm{BV}$ for the protein limiting in phenylalanine, leucine, methionine, tryptophan, valine, histidine and lysine were significantly higher $(P<0.05)$ than their AAS.

The expected values based on AAS and the actual protein utilization measured by BV were not the same for all the essential amino acids. It may be that Bender's (1965) standard does not adequately estimate the amino acid requirements. However, if we assume that the NPU value and BV for the low-protein diet are equivalent to the AAS, we should modify Bender's (1965) standard. Our proposed modified standard is presented in Table 5.

Our modified standard comprises the same amounts of S-amino acids, isoleucine and threonine but lower amounts of the remaining six amino acids. As shown in Table 5, the differences could be as much as $57 \%$ of Bender's (1965) standard for lysine and $85 \%$ for phenylalanine. The amounts of exogeneous amino acids are also lower in our proposed standard than those recommended by Hansen \& Eggum (1974) in their choice of standard for animals. Isoleucine is the exception: its level both in our standard and in Bender's (1965) standard is $43 \mathrm{~g} / \mathrm{kg}$ protein, while in other standards the value is at least $50 \mathrm{~g} / \mathrm{kg}$ and, in Hansen's \& Eggum's (1974) standard, the isoleucine level is $34 \mathrm{~g} / \mathrm{kg}$.

Utilization of protein of our proposed essential amino acid composition was investigated in rats to confirm experimentally whether the amino acid requirement was met when the rats were maintained on a low-protein diet. The study consisted of two series of experiments with dietary protein levels ranging from 45.5 to $45.8 \mathrm{~g} / \mathrm{kg}$ diet. Values for NPU, BV and TD are given in Table 6.

NPU was found to range from 0.89 to 0.96 (mean 0.92 (SD 0.023)) and BV was between 0.94 and 0.97 (mean 0.96 (SD 0.015)). BV was determined on the basis of NPU and true digestibility values. At the average digestibility of 0.96 (Table 6) the differences between $\mathrm{BV}$ and NPU were practically negligible. Thus, there was a greater similarity between results for NPU and BV, and AAS = 1 when calculated according to our standard as compared with AAS values calculated according to Bender's (1965). The latter value would be 0.58 , with lysine being the first limiting amino acid. The difference between the AAS value of 0.577 


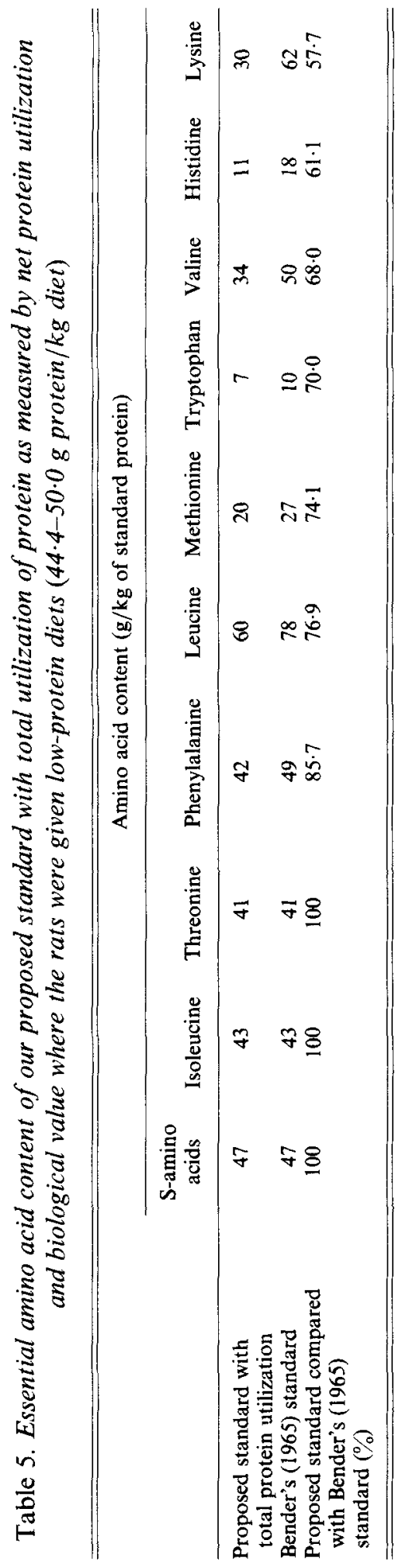


Table 6. Protein utilization value (NPU and $B V$ ) and true digestibility $(T D)$ of proposed essential amino acid standard determined for low-protein diets $(45 \cdot 5-45.8 \mathrm{~g}$ protein $/ \mathrm{kg}$ diet given to rats

(Mean values for four rats/group)

\begin{tabular}{cccc}
\hline \hline & Group & & \\
no. & NPU & BV & TD \\
\hline 1 & 0.93 & 0.97 & 0.96 \\
2 & 0.96 & 0.98 & 0.98 \\
3 & 0.89 & 0.94 & 0.95 \\
4 & 0.91 & 0.94 & 0.97 \\
5 & 0.89 & 0.97 & 0.92 \\
6 & 0.91 & 0.96 & 0.95 \\
7 & 0.93 & 0.97 & 0.96 \\
Mean & 0.92 & 0.96 & 0.96 \\
SD & 0.023 & 0.015 & 0.018 \\
\hline
\end{tabular}

NPU, net protein utilization; BV, biological value; TD, true digestibility.

obtained from Bender's (1965) standard and an NPU value of 0.920 would be 0.34 ; the difference between the BV value of 0.960 and AAS value of 0.577 calculated according to Bender's (1965) standard would be as much as 0.38 , while the corresponding differences between AAS values and NPU and BV values obtained using our standard were 0.08 and 0.04 respectively.

However, it can be demonstrated that the lack of the S-amino acids, isoleucine and threonine can influence protein utilization and does not depend on any standard of amino acid requirement. We have already shown that these three amino acids at similar dietary intakes are associated with similar body-weight loss, and this loss was greater than that produced by the other limiting amino acids. If amino acid composition and protein content of the diet are unchanged, protein utilization will depend on the amino acid which is limiting. Our results are in agreement with those of Said \& Hegsted (1970) and Chang. et al. (1977), who used young rats given $100 \mathrm{~g}$ protein $/ \mathrm{kg}$ diet. The latter authors investigated the effect of the limiting essential amino acid on the maintenance of body-weight. They found that the weight loss of the rats given diets without the S-amino acids, isoleucine and threonine was the same as that of rats given a protein-free diet, and that the lack of other essential amino acids in the diet caused a lower weight loss than that obtained with the protein-free diet.

Studies of the effect of the S-amino acids, isoleucine and threonine on protein utilization from the low- and medium-protein diets have been carried out using young and old rats (see Bender 1965; Said \& Hegsted, 1970; Ashida \& Yoshida, 1972; Chang et al. 1977). In our opinion the response of the animals and, at the same time, sensitivity of the biological indices were higher in the case of a low-protein diet. The effect of these amino acids was measured using biological indices and body-weight, and different standards of amino acid requirements were applied in each instance. Thus the similarity in the results suggests that these three amino acids differ from other essential amino acids but only quantitatively. The situation with respect to valine is unresolved (see also Bender, 1965; Said \& Hegsted, 1970; Ashida \& Yoshida, 1972).

When the effect of a particular limiting essential amino acid on utilization of protein is being assessed it can be assumed that the rats can use endogenous sources of all amino acids. At low-protein intakes amino acids derived from the tissues can play a large part in the metabolic amino acid pool and in maintaining NPU and BV at a higher level than the AAS. 
Values for protein utilization or biological quality of protein can be classified according to the particular limiting amino acid present. At a low level of intake, proteins deficient in S-amino acids, isoleucine and threonine and perhaps valine usually have the lowest NPU and BV, but higher values are attributed to the proteins limiting in the other essential amino acids in the order: phenylalanine, leucine, tryptophan, histidine, lysine.

The work was supported by grants from the National Food and Nutrition Institute.

\section{REFEREN CES}

Ashida, K. \& Yoshida, A. (1972). Proceedings of the Ninth Congress of Nutrition, Mexico 3, 321-331.

Bender, A. E. (1965). Proceedings of the Nutrition Society 24, 190-202.

Block, R. J. \& Mitchell, H. H. (1946-7). Nutrition Abstracts and Reviews 16, 249-278.

Chang, Y. O., Yokota, F. \& Mak, I. T. (1977). Nutrition Reports International 15, 231-238.

Hansen, N. C. \& Eggum, B. O. (1974). Acta Agriculturae Scandinavica 23, 247-251.

Miller, D. S. \& Bender, R. E. (1955). British Journal of Nutrition 9, 382-388.

Mitchell, H. H. (1924). Journal of Biological Chemistry 58, 873-903.

National Academy of Sciences (1972). Nutrient Requirements of the Laboratory Rat, no 56. Washington, DC:

National Academy of Sciences.

Rafalski, H., Jabłoński, E. \& Switoniak, T. (1978). British Journal of Nutrition 39, 13-18.

Said, A. K. \& Hegsted, D. M. (1970). Journal of Nutrition 100, 1363-1375. 